\title{
The Quranic Consonantal Text: Morphology
}

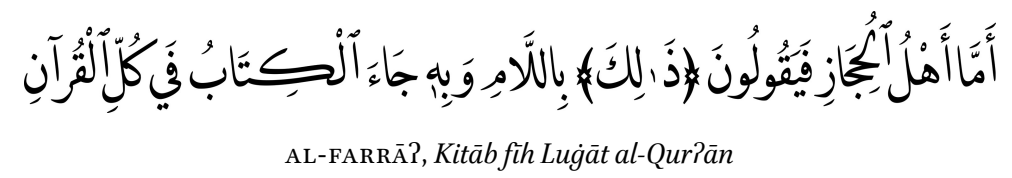

4.1 Introduction

In the previous section we have shown that when looking to answer the question what the language of the Quran is, the reading traditions fail to give a consistent answer. They are linguistically diverse, none of them look like natural language, and they must be considered to be a concerted effort to beautify the recitation of the Quran through the use of exotic linguistic features from a variety of different dialects, augmented with completely innovative forms that do not seem to have been part of anyone's natural speech. These reading traditions take shape with the eponymous readers, and it is difficult to see further back than these readers through internal reflection.

However, there is a source of the Quran that carries linguistic information that does go back to the very first decades of Islam: the written text itself. In recent years it has become clear that virtually every early Quranic manuscript that we have access to today goes back to a single archetypal copy (Cook 2004; Sinai 2014a; 2014b; van Putten 2019c). The dating of these manuscripts is so early that a date much later than the date attributed to it by the Islamic tradition (that is, during the reign of Sutmān b. Saffān, 644-656 CE) is quite difficult to envision. This primary source, while written in a highly defective script still carries a lot of linguistic information that we can likewise date back to this early period: the spelling is not random, but forms a clear system. This orthography must be seen as an important source of linguistic data, and its frequent deviations from the later standard Classical Arabic orthography can give us important insights into the nature of the language and how it differs from Classical Arabic. Moreover, as the Quran is a rhymed text, we receive a unique insight into some phonological features of the language which are not easily recoverable from other texts from this period, such as the early Islamic papyri. 
In a series of papers, I have already explored what the QCT can tell us about the phonology and nominal morphology of Quranic Arabic (van Putten forthcoming; 2017a; 2017b; 2018; 2019b; van Putten and Stokes 2018). What has not yet been explored, however, is the historical linguistic affiliation of Quranic Arabic. What morphological and phonological isoglosses does Quranic Arabic have? And how does it relate to pre-Islamic Arabic varieties as found in the epigraphic record and dialects as reported by the Arab grammarians?

Throughout modern Arabist literature, we find many statements that suggest that the Quran was written in a kind of mixed dialect, drawing freely from different dialects - much in the way as the Arabic poetry. The idea that the Quran was written in a mixed dialect seems to ultimately originate from the medieval Islamic tradition, but received its modern articulation in Chaim Rabin's monumental work on the Ancient West Arabian dialects where he stated with some confidence that the Quran was composed in the 'poetic koine' (Rabin 1951, 3f.). ${ }^{1}$ Rabin admits that the form of the poetic koiné used in the Hijaz may have had a local pronunciation, primarily, having lost the glottal stop as reflected in the orthography (Rabin 1951, 4 f.). However he tells us that "in morphology, on the other hand, an almost complete conformity with the 'Arabiyya' could be achieved" (Rabin 1951, 4). The claim then, is that morphologically we should be able to see that the text of the Quran adheres to the 'Classical Arabic' speech norms as opposed to the local dialect of the Hijaz.

This chapter will examine the morphological features of Quranic Arabic as reflected in the QCT, while the next chapter will tackle its phonological features. These features will be compared against the reports of the Arab grammarians as well as the linguistic data found in epigraphic pre-Islamic Arabic. From this discussion it will become clear that whenever the QCT allows us to identify linguistic features it almost universally agrees with what the Arab grammarians attributed to the dialect of the Hijaz, and as such Quranic Arabic should be understood as a reflex of a Hijazi Arabic vernacular and not "Classical Arabic". Moreover, frequently we will see that a large amount of the relevant isoglosses visible in the epigraphic record clearly point away from a northern origin, and on occasion give clear evidence that the isoglosses present in the QCT are an innovation typical for Hijazi Arabic.

In Al-Jallad's (2020b) revolutionary work on the Damascus Psalm fragment, he already listed several morphological features which appear to form unique Hijazi innovations in comparison to forms of Old Arabic found in Northern

1 Rabin $(1955,24)$ credits Fleisch $(1947,97-101)$, and Blachère $(1947,159-169)$ for coming to this conclusion independently from him that the Quran was composed in the poetic koiné. Neither author is much more informative as to what this elusive poetic koiné entails. 
varieties such as Safaitic, Hismaic and Nabataean Arabic. These isoglosses occur in Quranic Arabic as well, and as such, the language of the Damascus Psalm fragment and the Quranic Arabic are closely related to each other. Some of the isoglosses that can be identified as Hijazi innovations from the epigraphic record are also identified as typically Hijazi isoglosses by the Arab grammarians, and there are yet other isoglosses identified by the Arab grammarians for which not as much evidence has been found in the epigraphic record yet. In the following section we will look at morphological isoglosses present in Quranic Arabic as can be gleaned from the QCT which can either be compared to the epigraphic record, or those reported by Sībawayh and alFarrā? (or both). Whenever relevant, I will also cite the discussion of isoglosses that are discussed by Rabin (1951).

\subsection{The Palla- Base Relative Pronoun}

Quranic Arabic forms its relative pronoun on a base ?alla-followed by deictic elements ?alla-dí, ?alla-tī, ?alla-dinn etc. This form is innovative in relation to the ancient Semitic relative pronoun $\underline{d} \bar{u}$, a relative pronoun which continued to exist in Quranic Arabic with a more restricted possessive meaning 'possessor

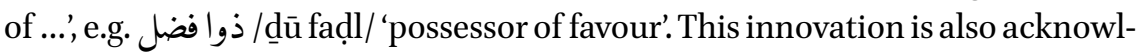
edged by Rabin $(1951,154)$.

The $\underline{d}$-base relative pronoun is the one that should likely be reconstructed for Proto-Semitic and is cognate to the Aramaic relative pronoun, e.g. Nabataean Aramaic דיזיז (Cantineau 1978, 61), Biblical Aramaic (Rosenthal 1961, 21f.) and Gəfəz $z \ddot{a}$. It is the relative pronoun found in the Northern epigraphic varieties of Old Arabic: Safaitic (m. $\underline{d}$, f.sg. $\underline{d}^{\prime} t, \underline{d} t, \underline{d}(?)$ pl. $\underline{d} w$, see Al-Jallad 2015, 85-88), and the one that seems to be attested in the Nabataean Arabic of the Namārah inscription: דו אשר אלתג / 205; Cantineau 1978, 49), cf. also the theonym דושרא /d̄u śarā/ 'the one of the Sharā mountain' (Cantineau 1978, 80).

The earliest attestation of the ?alla-base relative pronoun seems to be JSLih 384, an Old Arabic inscription in the Northern Hijaz, in the Dadanitic script, which has the feminine relative pronoun spelled ' $l$, presumably to be read / ?allatī/. See Müller (1982) and Macdonald (2000, 49) who identify the use of the Palla-base in this inscription as an Arabic isogloss, and see Al-Jallad (2015, 13, n. 17; 2018b, 8f.; 2020b, 6o) who identifies it as a specifically Old Hijazi isogloss within Arabic.

While the Palla-base is quite clearly an innovation and seems to have its origins in the Hijaz, by the time the grammarians start discussing the lin- 
guistic variation of Arabic, it seems to have become extremely dominant. Neither Sībawayh nor al-Farrā? consider any other relative pronouns. ${ }^{2}$ A few later grammarians attribute archaic forms of the relative pronoun to Yemeni dialects who used $\underline{d} \bar{\imath}$ (Rabin 1951, 39) and the Tayyi? who used $\underline{d} \bar{u}$ (Rabin 1951, 204f.).

\subsection{The Distal Demonstrative Expansion with -l(i)-in $\underline{\text { da lika, } t i l k a \text { and }}$ hunālika}

A typical feature of Quranic Arabic is the exclusive use of the distal demonstratives that have an additional element $-l(i)$ - between the demonstrative element and the addressee agreement suffix-ka/-kum etc. Thus, in the QCT we find and تاك tand never forms like ذاك tâ are reported for Classical Arabic (Wright 1896, §342; Fischer 2002, § 275a), and especially $\underline{d} \bar{a} k a$ occasionally occurs in poetry and Classical Arabic prose (often co-occurring besides $\underline{d}$ àlika).

The difference between these two pronouns is widely identified as a Hijazi isogloss already in the time of al-Farrā? (Luġa $t, 11)$, who recognizes the exclusive use of the da alika form as typical for the Quran and attributes it to the Hijaz, while the people of Najd among the Qays, Rasad, Tamìm and Rabīiah use $\underline{d a} k a$. As far as can be gleaned from the fragmentary pre-Islamic data, it seems that the archaic forms without the $-l(i)$ - insertion were original to the northern Old Arabic varieties, and that $-l(i)$ - extension is a Hijazi innovation (Al-Jallad 202ob, $61 \mathrm{f}$.). $t k$ as a feminine distal demonstrative appears to be attested in a single Safaitic inscription (Al-Jallad 2015, 84).

While Rabin $(1951,154)$ recognizes the identification of the $-l(i)$ - extension as Hijazi, he remains skeptical of this identification because some Western Arabs have sayings and poems attributed to them that use $\underline{d} \bar{a} k a$ as well. He is also suspicious of the claim because Arab grammarians that claim this to be a Hijazi feature tend to cite the Quran as evidence for this, as it exclusively has - li- extension. This seems to me to be the wrong conclusion based on the facts available.

First, as $\underline{d} \bar{a}$ lika is the innovative form and $\underline{d} \bar{a} k a$ the original, the fact that an archaic form is used by Western Arabs_-assuming this attribution is valid-is hardly an argument why dealika is not a Hijazi feature. At most it is an argument

2 Al-Farrā? (Luġāt, 12) does talk about relative pronouns however, and attributes an inflecting form of the plural to Hudayl: nom. alladūna obl. alladinna. 
that $\underline{d} \bar{a} k a$ is not an exclusively eastern feature. Just because $\underline{d a} k a$ occurs in the Hijaz as well, does not exclude the possibility that $\underline{d a} l i k a$ is indeed a uniquely Hijazi innovation.

His second point seems to presuppose the conclusion that the Quran is composed in the poetic koine and therefore cannot be evidence of dialectal data, but this has not been demonstrated by him, nor by anyone else. The very fact

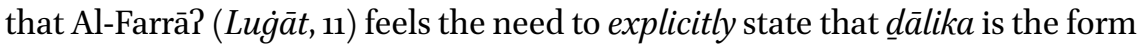
that occurs in the Quran in fact highlights that this is a fact considered remarkable and distinctive of Quranic Arabic, and something that he did not consider to follow automatically from the statement that this is the Hijazi form.

In Classical Arabic prose and poetry alike $\underline{d} \bar{a} k a$ and $\underline{d} \bar{a} l i k a$ co-occur, and its absence in the Quran is in fact striking, and a clear deviation from the Classical Arabic norms. The very fact that al-Farrā?, nor any other grammarian, feels the need to attribute all features present in Quranic readings to the Hijaz (as we saw in chapter 3), seems to confirm that the observation on the Hijazi character of da $\bar{a}$ lika is quite independent from the observation that it is the only form that occurs in the Quran.

To da $\bar{a}$ lika and tilka, we may also add that the distal locative demonstrative receives the $-l(i)$ - expansion to form هن rather than hunāka as a Hijazi feature (al-Farrā? Luġăt, 47). The Tamimi hunāka becomes the dominant form in literary Arabic production but is absent in the QCT.

\subsection{The Plural Demonstratives (hā-)?ulā?i/(hā-)?ulā; Pulā?ika/Rulāka}

Another isogloss that is attributed to the Hijaz is the shape of the plural distal demonstrative. Here al-Farrā? (Luġăt, 12) reports Pulā?ika for Qurayš and the people of the Hijaz, while ?ulāka is reported for Qays, Tamīm, RabīYah and Pasad, Pullāka for some of the Banū SaYd and Tamìm, and Pulälika for "some of them". ${ }^{3}$ The QCT is unambiguous in this regard as it only attests the spelling and never اولاك and therefore it is only compatible with the Hijazi form. ${ }^{4}$

The proximal plural demonstrative likewise is reported by al-Farrā? (Lugiāt, 22) to have a difference between Qurayš and those that surround them who have hââlä?i as opposed to Tamim, Qays, Bakr and the common people of

3 From the context it is unclear whether Al-Farrā? intends "some of the Banū SaSd and Tamīm" or "some of the Arabs". Considering that the - $l(i)$ - infix is a Hijaz feature in the singular forms, it seems probable that the latter is intended, and that it is a feature found, probably, among some Hijazis, but this is not made explicit.

4 For this isogloss see also Rabin $(1951,153, \S g)$. 


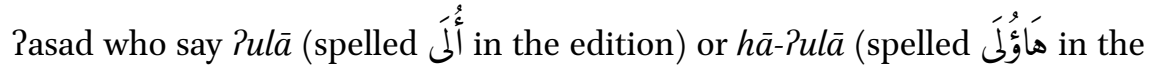
edition) with an Palif maqșūrah (as opposed to an Palif mamdüdah). He adds that 'some Arabs' drop the first ?alif of the word and say hawlä?i and cites a piece of poetry that adduces this. ${ }^{5}$

The QCT does not allow us to infer with certainty the shape of the proximal deictic (although it definitely has the initial $h \bar{a}-$ ), as both ?alif and $y \bar{a}$ ? can represent the Palif maqșürah whereas ?alif can also represent Palifmamdūdah. Thus, the QCT هو لا is consistent both with hā̃ulā?i and hā?ulā.

However, al-Farrā? explicitly writes the Palif maqșūrah with a $y \bar{a}$ ?, which means he likely intended the Najdi pronunciation to have been $(h \bar{a}) ? u l \bar{e}$, since the Kufans, including his teacher al-Kisā?ī, would regularly read Palif maqșürah bi-sūrat al-yā? with Pimālah (see § 3.6.4.2). ${ }^{6}$ Since the QCT distinguishes between /ê/ (spelled with $y \bar{a}$ ?) and /âa / (spelled with Palif) the QCT would only be consistent with $h \bar{a}$ ?ulā?i and not with $h \bar{a} ? u l \bar{e}$.

\subsection{Proximal Deictics with Mandatory $h \bar{a}$ - Prefix}

In the QCT all proximal deictics, be they masculine هذا هذه هذه, feminine, plural هو or or locative prefixed by $h \bar{a}$-. This is remarkably different from what is reported from Classical Arabic where forms without $h \bar{a}$ - are broadly reported, e.g. masculine $\underline{d} \bar{a}$, feminine $\underline{d i h}, \underline{d} \bar{i}, t \bar{t}$ plural $i u l a \bar{a}$ locative hunā. In Classical Arabic prose especially the form hunä-absent in the QCT—becomes standard, while others are rare.

Al-Farrā? (Lug $\bar{a} t, 22)$ reports the addition of the $h \bar{a}$ - prefix as optional for the plural among eastern tribes, but mandatory in the Hijaz. Forms without $h \bar{a}$ - are not explicitly mentioned for singular masculine $\underline{d} \bar{a}$ or feminine $\underline{d} \bar{\imath} / \underline{d} i h$ by al-Farrā?, although later grammarians like al-Zamaxšarī (al-Mufașșal, 55) do report them. Even the locative deictic consistently has the $h \bar{a}$ - prefix in Quranic Arabic هنه 'here' (Q3:154; Q5:24; Q26:146; Q69:35).

In the pre-Islamic record, we find that the Northern varieties consistently lack the addition of the $h \bar{a}$ - so its mandatory addition appears to be a typical

5 It is interesting to note that "dropping of the ?alif" for al-Farrā? seems to mean that a $\bar{?} u$ automatically becomes $a w$, while one might expect it to become $a ? u$ instead. With this single occurrence it is difficult to decide what to make of this observation.

6 Modern mesopotamian dialects that retain a reflex of word-final $\bar{e}$ as $-i$ (habli) occasionally seem to treat Palif mamdūdah the same way, hence šati 'winter'. This seems to point to a merger of word final ${ }^{*}$-ay-and word final ${ }^{*}-\bar{a} y$ - towards $\bar{e}$ before the shift of ${ }^{*}-\bar{a} y$ - to $-\bar{a}$ ?- took place, cf. Safaitic śty /śetāy/ 'winter'. See on this topic also Levin (1992, especially 86 f.). 
innovation of Quranic Arabic. For example, Safaitic only attests $\underline{d}$, presumably / āā/ (Al-Jallad 2015, 80), and the same is true for the late Nabataean Arabic inscription at Harran (568CE), which clearly attests دا المرطول/dā al-marțūl/ 'this Martyrion' (Fiema et al. 2015, 414), a feminine deictic תי whout the initial $h \bar{a}$-is likewise attested in the Nabataean Arabic of the Namārah inscription, e.g. תינפש (328CE) (Fiema et al. 2015, 405). Thus, while the epigraphic data does not allow an identification of this isogloss of typical for the Hijaz, it is clear that North of the Hijaz the addition of the $h \bar{a}$ - was not mandatory, as no attestations of it have been found so far.

\subsection{Feminine Proximal Deictic hädih}

According to Sỉbawayh (IV, 182) the Tamīm dialect has the feminine proximal deictic $h \bar{a} \underline{d} \bar{\imath}$ form in context which becomes $h \bar{a} \underline{d} i h$ form in pause. This is also what Rabin $\left(1951,152\right.$, §f) claims is the "strict Classical Arabic" form. ${ }^{7}$ The Hijazi dialect would have borrowed this pausal form from Classical Arabic. No argument is given why it would not be the other way around or how he envisions a spoken dialect like Hijazi would go about borrowing such a basic category as a demonstrative from a poetic register. The existence of $t \bar{l} / t \bar{a}$ demonstratives in hadit țs ${ }^{8}$ and poems does not disprove that the $h \bar{a}$ dih form was the common form in the Hijaz - only that some archaic forms were also in use, if we would accept that poetry and hadīts are representative of Hijazi Arabic. The feminine proximal deictic throughout the QCT is هذه, which is in line with the report for Hijazi Arabic, which is said to use hādih(ī) both in pause and context.

In the northern Old Arabic dialects evidence is found for both $t \bar{\imath}$ and $\underline{d} \bar{\imath}$ but not $(h \bar{a}-)$ dihi . For example, the ancient Namārah inscription (dated $328 \mathrm{CE}$ ) written in Nabataean Arabic starts with תי נפש this is the funerary monument of .... Safaitic seems to attest a feminine demonstrative that has an initial $\underline{d}$, presumably / $\mathrm{d} \overline{\mathrm{i}} /$, rather than $t$ a feminine deictic also reported by the Arab grammarians (Al-Jallad 2015, 81). The forms with final $h$-the only form found in the Quran-is currently unattested in pre-Islamic Arabic.

7 I do not understand what the category of "strict Classical Arabic" is based on. It would imply that Sïbawayh's own prose is not a representation of 'strict Classical Arabic', as he exclusively uses hā $\operatorname{dih}^{\prime} \bar{i}$ in context.

8 In fact, the prophetic narration that Rabin cites does not have the proximal deictic, but rather the distal deictic: kayfa ti-kum 'how is that one (spoken to a plurality of addressees)?' As prophetic narrations are not necessarily verbatim narrations, the use if $t \bar{t}-k u m$ probably says more about the dialect of ؟āiišah (who narrates this tradition), or the common link of this Hadith (which seems to be Ibn Šihāb al-Zuhrī) than it does about the prophet's speech. 
As discussed in $\S$ 2.2.5, Sībawayh and al-Farrā? agree that one of the features absent in Hijazi Arabic that is present in all other dialects is the use of $i$-prefixes in the prefix conjugation of stative fa Sila verbs, thus they say Panā Pi Slamu dāka 'I know that' rather than the Hijazi ?ana ?aSlamu da älika. ${ }^{9}$

The Barth-Ginsberg alternation must certainly be reconstructed for ProtoArabic (see $\S 2.2 .5$ ). Thus, the disappearance of it is a specific innovation typical of Hijazi Arabic. Indeed, there is evidence for this being a Hijazi innovation from the epigraphic record as well: Two Graeco-Arabic inscriptions from North Arabia attest verbs that unambiguously have $i$-prefixes with a stem vowel $a$ : ıpav /yirfaw/ 'they pastured' (Al-Jallad and al-Manaser 2015) and $\varepsilon \sigma \rho \alpha \tau /$ yisrat/ 'he served in the army' (Al-Jallad et al. 2020). There is epigraphic evidence in the Northern Hijaz of the innovative generalization if the $a$-prefixes, namely in a Greek inscription which contains the name I $\alpha \lambda \eta$ (UJadhGr 2) (Nehmé 2018, 286f.), identified by Ahmad Al-Jallad (personal correspondence) as representing the Arabic verbal name /yailē/, rather than the expected /yillē/, had Barth-Ginsberg been operative. Thus, the epigraphic record seems to confirm that the lack of Barth-Ginsberg alternation is a Hijazi isogloss, in line with the reports of the grammarians.

In the QCT it is generally difficult to find unambiguous evidence for or against the Barth-Ginsberg alternation of the prefix, because of the short vowels being unwritten. However, there are two types of verbs, identified by Sībawayh and al-Farrā? alike, where this dialectal difference shows up in the consonantal skeleton of the text. As they both point out, stative verbs with I-w and I-? stems, in the case of the application of Barth-Ginsberg, will end up with a $y \bar{a} ?$, thus one gets tïgalu 'you fear' and tỉbā 'you refuse' (Sībawayh, IV, 111). In this place, the QCT provides us with evidence that Quranic Arabic follows the لا توجل Hijazi innovation of not having Barth-Ginsberg alternation, as we find /lā tawğal/ 'do not fear!' (Q15:53) rather than ** لا تيجل explicitly mentioned by al-Farrā? $(L u \dot{g} \bar{a} t, 8)$ to be the expected form in the non-Hijazi dialects. For the I-? stems, we find more evidence in the QCT that the Barth-Ginsberg alternation did not operate: ان تامنه /Pin tāman-h/ 'if you entrust him' (Q3:75, twice), الا تامنا /lā tāman-nā/ 'you do not entrust us' (Q12:11), تالمون/tâlamūn/ 'you are

9 For this feature, see also Rabin $(1951,158, \S p$, q), who suggests that this feature is borrowed from North-West Semitic, rather than a shared retention. This seems to be the result of imposition of the late Classical Arabic norms which lacks this alternation, taking this standard as a stand-in for Proto-Arabic. There is no obvious reason to assume that the Classical Arabic situation is original in this case. 
suffering' (Q4:104, twice), فلا تاس /fa-lā tās/ 'so do not grieve' (Q5:26, 68), كئا

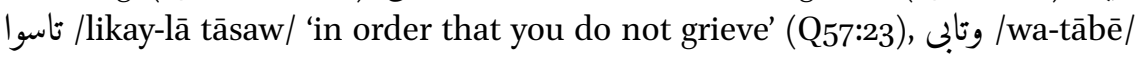
'but [their hearts] refuse' (Q9:8). اسى /āsē/ 'I grieve' (Q7:93), ان ادن /an ādِan/ 'that I give permission' (Q7:123; Q20:71; Q26:49), امنك /Rāmanu-kum/ 'I entrust you' (Q12:64); لا ياب /lā yāb/ 'he should not refuse' (Q2:282, twice); فلا يامن /fa-lā yāman/ 'he does not feel secure' (Q7:99); ويابن /wa-yābē/ 'and he refuses' (Q9:32)

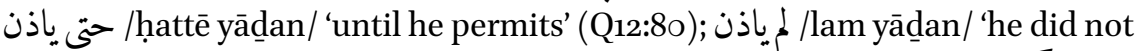

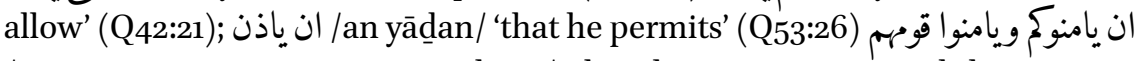
/an yāmanū wa-yāmanū qawmahum/ 'that they entrust you and they entrust their people' (Q4:91); يالمونك/yālamūna/ 'you are suffering' (Q4:104).

These examples thus confirm that Quranic Arabic follows the innovative Hijazi practice of lacking the Barth-Ginsberg alternation.

\subsection{Uninflected halumma}

Rabin (1951, 162 f., §z)—following al-Farrā? (Lug̀āt, 63) and Sībawayh (III, 529) - points out that in the Hijaz halumma 'come on!' was uninflected, while the Tamìm conjugated it as an imperative verb, sg.m. halumma, sg.f. halummī, du. halummā, pl.m halummū pl.f. halmumna, (al-Farrā? reports the unexpected feminine plural forms halummanna, halumunna). In the QCT, هis is uninflected in the two places it occurs (Q6:15०; Q33:18), which in both cases has a plural addressee. The QCT therefore agrees with the Hijaz in this regard. The Hijazi form here is probably archaic, as it seems likely that this is a presentative particle $h a l^{10}$ followed by -umma, the same particle as the vocative suffix that one finds in alläh-umma 'O God!' The innovation of the Tamìm would have then been to interpret this as an imperative verb. ${ }^{11}$

\subsection{Imperatives and Apocopates of II =III Verbs Have the Shape vCCvC Rather Than (v)CvCC}

Imperative and apocopates of geminate verbs have a metathesized form in non-Hijazi dialects $(\operatorname{urudd}(a / u))$, whereas in the Hijaz they are un-metathesized (urdud) (Rabin 1951, 161 f., §y). This according to Rabin $(1951,4)$ is one of "the few Hijazi forms [...] that appear sporadically [in the Quran]". It should be

10 Compare for example Ugaritic $h l$ 'see; here is/are; now (then)' (Huehnergard 2012, 146).

11 I thank Ahmad al-Jallad for suggesting this analysis to me. 
clear by now that many more Hijazi features than just the treatment of geminate verbs appear in the Quran. The claim that this form is sporadic among the readers is not in keeping with the attestations in the Quran. The unmetathesized Hijazi form is the norm. The apocopate occurs without metathesis 43 times, and the imperative 8 times. The metathesized forms never occur for the imperative, and for the apocopate there are only three, or four cases. The first is يشاق 'opposes' (Q59:4), while the unmetathesized form of the same verb is attested as يشاق 'يشاق 'opposes' (Q4:115). The second and third are تضار 'suffers' (Q2:233) and يضار 'suffers' (Q2:282), which do not occur in unmetathesized forms elsewhere. The last case is a bit more involved. In the Kufan and Basran codices يرتد ير يرتد 'turns back' (Q5:54) occurs besides back' (Q2:217) (Al-Dānī muqniS, 107), but in the Syrian and Medinan codices Q5:54 is spelled

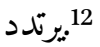

Rabin suggests that the Hijaz used the unmetathesized forms exclusively, while the Tamim used the metathesized forms. This is indeed how Sỉbawayh (III, 529-532) reports it. However, al-Farrā? (Luġāt, 36) seems to accept the possibility of metathesized forms in Hijazi dialects as he says that Hijaz and Pasad place the vowel $a$ after metathesized final root consonants such as in tudârra while Tamim and Qays have tudārri. The isogloss therefore seems to be that Hijazi was able to use both metathesized and unmetathesized forms whereas Tamim used the metathesized forms exclusively. The QCT overwhelmingly has forms that are not metathesized, clearly showing this Hijazi isogloss. The metathesis found in Hijazi would appear to be a reflex of a type of assimilation across syllable boundaries that occasionally occurs in the QCT, also in other positions (see Appendix A.3.5 for a discussion).

\subsection{Mā hịiḡāziyyah}

The vast majority of the nominal negation using $m \bar{a}$ is constructed with the predicate marked with $b i-$-, e.g. وما هم بمومنين 'they are not believers' (Q2:8). Only on rare occasions is the $b i$ - left out, and in those cases a disagreement is said to occur between the people of the Hijaz and Najd. This much is also admitted by al-Farrā? (Lug்ăt, 28): "the people of the Hijaz say mã zaydun bi-qā?im 'Zayd is not standing', and hardly ever do they drop the $b i$ - from their speech,

12 It is surprising that Rabin $(1951,162)$ reports to not have found variants for Q5:54, as yartadid is the reading of the canonical Syrian and Medinan readers, Ibn Yāmir, Nāifi and Pabū ĞaSfar-in accordance with their regional rasm (Ibn al-Ǧazarī, § 2989). 
and this is how it is in the Quran except in His speech: $m \bar{a} h \bar{a} \underline{d} \bar{a}$ bašara $\bar{a}$ and mā hunna ?ummahäti-him, they apply the accusative when they leave out the $b i$ - Tamim, Qays and Pasad (also) say it with the $b i$-, but when they remove the $b i-$, they apply the nominative."13 This use of the accusative is usually known as Mä Hiǧăziyyah, whereas using the nominative is called the Mã Tamimiyyah, this feature is well-known among the grammarians (see also Sïbawayh, I, 57). At the time of writing, Rabin $(1951,174 \mathrm{ff}$., $§ \mathrm{p}-\mathrm{t})$ seemed to lack sources that explicitly comment on the frequency of this construction, and as he points out it seems to have been quite rare. We now know that this was also recognized by $\mathrm{Al}$-Farrā? as well. Indeed, in the QCT, only one unambiguous case of the $m \bar{a}$

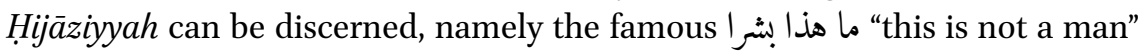

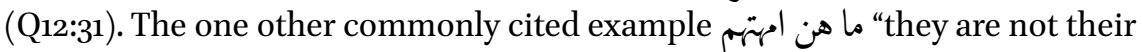
mothers" (Q58:2), universally read in the Hijazi manner by the canonical readers mā hunna ?ummahäti-him $(\bar{u})$ (not Pummahâtu-hum $(\bar{u})^{14}$ ) is ambiguous in the QCT, and could reflect both the mā hiğazziyyah and the mā tamimiyyah. Rabin tentatively supplies another option ما منكم من احد عنه جزئ "not one of you can shield against it" (Q69:47). This one does show the Hijazi form in the QCT, but does not get commented upon by the Arab grammarians, perhaps because they took hăğizina as a hăal.

As pointed out by al-Farrā? and Rabin, all other cases of nominal negation with $m \bar{a}$ mark the predicate with $b i$. The anomalous nature of ما هذا (Q12:31) was the reason for Ahmad al-Jallad (2020b, 68f.) to suggest that it is a grammatical anomaly included as a conscious choice in the direct speech, perhaps to give a colloquial effect to the quotation in the Quran. He likewise observes that another grammatical anomaly, the famous ان هذان لسحران "These two are wizards!" (Q20:63), likewise occurs in direct speech. It should be noted that, unless there is another plausible interpretation of ما هن امهتك , the use of the nominal negation with $m \bar{a}$ without $b i$ - seems exceedingly rare, but not unique to direct speech. With the caveat that this is admitted to be a marginal feature in the Hijaz as well as that it is extremely marginal in the Quran, the grammarian data does seem to assign a Hijazi origin to the isogloss that find in the QCT.

13 Pahlu l-hiğāàiyaqūlūna: mā zaydun bi-qāPimin, fa-lā yakādūna yulqūna l-bā?a min kalāmihim, bi-dālika ğāia l-quriānu Pillā qawlahū "mā hāḍā bašaran", "mā hunna iummahātihim" wa-yanșibūna ?ị̂ā Palqawi l-bā̃. tamìmun wa-qaysun wa-?asadan yaqūlūna bil-bā?i, fa-Pidāa țarahū l-bāîa rafậu.

14 Although the non-canonical transmitter of Yāṣim, al-Mufaḍdal, is said to have read this with the nominative (Ibn Muğāhid, 628; Ibn Xālawayh, 154). 


\subsection{The Morphosyntax of kāla}

Al-Farrā? (Ma९́̄nī, II, 245f.) tells us that there is disagreement on the how the verb $k \bar{a} l \bar{u}$ "to allot s.th. to s.o." should be treated. He says that the people of the Hijaz and those that neighbour Qays treat the recipient of the allotment as a direct object, giving examples such as qad kiltu-ka țąāman kațīran 'I have allotted to you a lot of food', and kilta-ni 'you have allotted to me', the more regular syntax appears to be with the preposition li-, i.e. kilta lì and kiltu laka. As al-Farrā? points out himself, the QCT follows the Hijazi practice in this regard كالوهم 'they allotted to them' (Q83:3).

\subsection{The Presentative häPum}

Al-Farrā? (Luġāt, 143f.) reports a difference between the presentative particle $h \bar{a} a_{a}$ 'voilà' and how it is inflected among the people of the Hijaz in contrast to the people of Najd (Qays, Tamìm, Pasad). The Najdi tribes treat this presentative particle morphologically as an imperative verb, whereas the Hijazi dialect seems to base its endings on the 2sg. pronominal endings where the $k$ has been swapped out with $?$ for unclear reasons. Al-Farrā? also reports that it has reached him that some Arabs indeed have $k \bar{a} f$ in place of the hamzah giving as example $h \bar{a}-k a$ and $h \bar{a}-k i$.

\begin{tabular}{|c|c|c|}
\hline & Hijaz & Najd \\
\hline m.sg. & $h \bar{a} ? a$ & ha? or hāîa \\
\hline f.sg. & hāei & $h \bar{a} P \bar{\imath}$ sometimes $h \bar{a} P i$ \\
\hline dual & hā?umā & $h \bar{a} ? \bar{a}$ \\
\hline m.pl. & hā?um & $h \bar{a} P \bar{u}$ \\
\hline f.pl. & hāPunna & ha?na \\
\hline
\end{tabular}

While this presentative particle is not attested particularly often in the QCT, the one time it does show up, it clearly takes on the Hijazi morphological form oاوم (Q69:19). 


\subsection{The Use of Zawğ as 'Wife'}

One of the reported differences between Hijaz as opposed to Tamīm and many of Qays and the people of Najd, according to al-Farrā? (Lugia $t, 3^{2-33)}$ is that zawğ is a unisex word meaning both 'husband' and 'wife' depending on the context in Hijazi whereas in the east zawğ is 'husband' and zawğah is 'wife'. The QCT clearly aligns with the Hijazi distribution, e.g. يادم اسكن انت وزوجك ' الجنه 'O Adam, dwell, you and your wife, in Paradise' (Q2:35).

\subsection{Alternations between G- and C-stems}

On multiple occasions al-Farrā? (Luḡāt) reports that some dialects have a Cstem where other dialects have a G-stem, with the same meaning. These are in essence lexical isoglosses, based on what kind of morphology they follow, and they allow us to compare them against what we see in the QCT. We find that whatever is reported to be the Hijazi form is the form that we find in the QCT. Verbs reported to have a C-stem in the Hijaz, and a G-stem elsewhere, are the following:

- Pawhāa 'to inspire’ (Hijaz), waḥā (Pasad), p. 146. QCT: Hijazi اوقى (Q99:5).

- Pawfā 'to fulfill' (Hijaz), wafā 'id.' (Najd), p. 49. QCT: Hijazi اوفى (Q3:76) 'he fulfills'.

Cases where the Hijaz rather has the G-stem whereas other tribes have a C-stem are more numerous, examples of these are the following:

- fatana 'to tempt' (Hijaz), ?aftana 'id.' (Tamīm, RabīYah, ?asad, Qays), p. 57. QCT: Hijazi فن (Q29:3).

- haruma 'to be forbidden', harām pl. hurum 'forbidden' (Hijazi), ?ahrama 'to be forbidden', muhrim 'forbidden' (?asad, Tamīm, Qays), p. 6of. QCT: Hijazi الحرام (Q2:144).

- Yaṣafa 'to blow violently' (Hijaz) PaSșafa (Pasad), p. 73. QCT: Hijazi G-stem active participle عاصف (Q10:22; Q14:18); عصفت (Q21:81); (Q77:2), rather than the C-stem muৎșif.

- marağa 'to release' (Hijaz), ?amrağa (Najd), p. 108. QCT: Hijazi مه (Q25:53; Q55:19).

In one case the QCT seems to have both the G-and the C-stem with the same meaning attested.

- nakira 'to not know' (Hijaz), ?ankara (Pasad, Tamīm), p. 75. The QCT uses the G-stem once نكرهم 'he did not know them' (Q11:70), the C-stem usually means 'to reject, deny' e.g. ينكرونم 'they deny it' (Q16:83), but the active participle at least once seems to have the G-stem meaning in Q12:58 وهم له منكرون 'they did not know/recognize him'. 
These lexical isoglosses of verbal stem formation in the QCT therefore seem to follow the patterns as they are reported for the Hijazi dialect.

\subsection{Morphological Isoglosses Not Recognized by the Grammarians}

In Quranic Arabic, there are several morphological developments which based on comparative evidence with modern dialects and Old Arabic must certainly be seen as innovations typical of Quranic Arabic, yet are not recognized or discussed as isoglosses by the Arab grammarians. In these cases, whatever we find in Quranic Arabic is identical to the Sarabiyyah - that which the grammarians describe as valid and eloquent Arabic. While these do not help us better classify Quranic Arabic within the context of the dialects as described by the grammarians, they occasionally do allow us to set it apart from modern dialects and attested forms of Old Arabic in the epigraphic record.

\subsubsection{Ta-prefix in Prefix Conjugation of tD-and $t L$-stems}

In Gə९əz, the tD- and tL-stems the suffix conjugation has the shape $t \ddot{a}$-for the formation prefix whereas the prefix conjugation has the shape $t$-, i.e. täqätțälä, yatqätțäl. Classical Arabic has ta- in both forms, while most modern dialects have $t$ - in both stems. It was already noted by Diem (1982) that these $t$-forms cannot be explained as the outcome of regular sound change from $\mathrm{ta}^{-}$, and therefore both the $t a$ - and $t$ - forms must have been around in Proto-Arabic. He subsequently suggests that Proto-Arabic probably had the distribution as it is attested in GəSəz. Since Diem's article, dialectological data has become available that shows there are dialects that generalize the $t a$ - like Classical Arabic, and more importantly, that there are some rare dialects that indeed retain the alternation as it is present in GəYəz. See for example: Douz Arabic tịaššam/yithaššam 'to be ashamed', tạārak/yiţārak 'to fight' (Ritt-Benmimoun 2014, 349-350; 355-357), ${ }^{15}$ Gulf Arabic tag்ayyir/yitgayyar 'to change', tiwāfag/ yitwāfag 'to help each other' (Holes 2010, 404f.) and finally in Saudi Arabic we find Ghāmid takallam/yitkallam 'to speak', Qauz tikallam/yitkallam 'to speak', Hofuf taharrak/titharrak (3sg.f.) 'to move' (Prochazka 1988, 40-50). From this evidence we must conclude that this alternation of the $t a$ - and $t$ - prefix can securely be reconstructed for Proto-Arabic. The fact that this aligns with what we find in GəSəz, make it clear that this allomorphy can even be reconstructed for Proto-West Semitic.

15 The ultrashort vowels ${ }^{i}$ and ${ }^{\text {a }}$ are the regular outcome of ${ }^{*} a$ in open syllables. 
While the evidence is sparse, the data available suggest that Quranic Arabic underwent the same generalization as Classical Arabic. For the suffix conjugation it is clear it always has the $t a$ - prefix, because it does not have a prothetic Palif to break up the CC cluster, e.g. تقطع 'to be severed' (Q6:94) rather than *** اتقطع that one would expect for **/itqatțaI/. Evidence that the prefix was $t a-$ in the prefix conjugation is sparser, but it can be deduced from يتاخ (that) he stay behind' (Q74:37), which could only represent /yatāxxar/ or if the hamzah is retained in this context /yata?axxar/. Had the prefix been $t$ - we would have expected ** for/yataxxar/from *yat?axxara.

Thus, we can conclude that Quranic Arabic has innovated by generalizing the $t a$ - prefix to both suffix and prefix conjugations. This generalization seems to have become the prestigious form early on, as any mention of a situation with $t a$-/t- alternation or a generalized $t$ - so abundant among the modern dialects seems to be entirely absent in the descriptions of the Arab grammarians. It is thus a clear morphological innovation of Quranic Arabic compared to Proto-Arabic, but it is not explicitly attributed to the Hijaz.

\subsubsection{N-prefix in the Suffix Conjugation of N-stems}

Much like the $\mathrm{tD}$ - and tL-stems, the N-stem appears to have had a vocalized allomorph $n a$ - in the suffix conjugation and an unvocalized allomorph $-n$ - in the prefix conjugation in Proto-Arabic. Evidence for this distribution is found in Safaitic where the lack of assimilation of the $n$ in the suffix conjugation such as in $n \dot{g} d b$ /nagș̣aba/ 'he was angered' clearly suggests a vocalised prefix. The form yqtl /yiqqatel/ 'to be killed' on the other hand appears to represent an assimilated $n$-prefix (Al-Jallad 2015, 134ff.). The fact that this Old Arabic reflex finds a parallel outside of Arabic in, e.g. Hebrew Pf. nip̄ "na-pYala, "yi-n-paSilu (Suchard 2019, 49f.) suggests that Safaitic retains the Proto-Arabic situation. Quranic Arabic, like Classical Arabic and, to my knowledge, all modern dialects has generalized the unvocalized allomorph $-n$ - to both stems, yielding forms such as pf. انقلب 'he turned' (Q22:11) impf. ينقلب 'he turns' (Q2:143). While the Arab grammarians do not comment on the vocalized prefix form at all, from the epigraphic record and comparative Semitic data it is clear that the Quranic Arabic form is innovative.

\subsubsection{The ?an yafYala Verbal Complement Construction}

Al-Jallad (2020b, 61) identifies the ?anyafiala verbal complement construction as yet another isogloss of Hijazi Arabic, in contrast to epigraphic Old Arabic. Both the language of the Quran, and the Old Hijazi of the Damascus psalm fragment form verbal complements with the particle ?an followed by the subjunctive verb, where in Old Arabic of the Levant and North Arabia an infinitive 
construction would be used (Al-Jallad 2015, 112f.). This seems to be a Hijazi innovation, as its earliest attestation occurs in a fragmentary Dadanitic inscription from al-Sulā in the Northern Hijaz (Al-Jallad 202ob, 61). However, this is an innovation that Quranic Arabic shares with Classical Arabic, and is thus not identified as a Hijazi isogloss by the grammarians.

\subsubsection{Use of the Definite Article al-}

An interesting isogloss that is not exclusive to the Hijaz, but nevertheless forms a clear linguistic isogloss in the Old Arabic linguistic record is the shape of the definite article. In the Old Arabic present in the corpus of Safaitic inscriptions the definite article is usually represented by a $h$ - (presumably /haC-/), not infrequently '- and only rarely by $h n$ - or ' $l-($ Al-Jallad $2015,11, n .10)$, and the Old Arabic of the Hismaic corpus seems to lack a definite article altogether (Al-Jallad 2018b, 12). In Nabataean Arabic, on the other hand, it is always written אל, suggesting an unassimilated /al-/ in all contexts. This same lack of assimilation is also found in the Arabic of the Damascus psalm fragment (AlJallad 2020b, 24). For Quranic Arabic, the evidence is difficult to interpret, the QCT would suggest an unassimilated article, but this might be a purely orthographic convention — as it is in Classical Arabic — adopted from the Nabataean writing system. Van Putten (2019b, 14f.) gives some not particularly binding arguments why an assimilated article before apical consonants, as in Classical Arabic, might be preferable over an unassimilated situation as found in the Damascus psalm fragment. Whatever the interpretation of the QCT in this case, that it uses the $a l$ - article, as opposed to the $h a C$ - article, the Yemeni an/am-articles or a completely absent definite article certainly distinguishes it from the Old Arabic present in the northern varieties of Safaitic and Hismaic, and puts it closer to Nabataean Arabic in this regard. The early Arab grammarians, however, do not recognize this as a Hijazi isogloss at all, and rather see the al- article with assimilation as the only acceptable form of the farabiyyah.

\subsection{Questionable Morphological Isoglosses}

There are a few morphological isoglosses of the Hijaz discussed by Rabin (1951) which can be deduced from the QCT where it does not agree with the reported Hijazi form. However, in these three cases, we will see that it is to be doubted whether the isogloss is to be attributed to the whole Hijaz, or to the Hijaz at all, as early sources of the grammarians give conflicting reports. 


\subsubsection{The III-w Passive Participle Is maCCuww Not maCCiyy}

Al-Farrā? (MaYānī, II, $169 \mathrm{f}$.) claims it is a linguistic practice of the people of the Hijaz to retain the consonant " $w$ in passive participles of III- $w$ stems, e.g. marهرضيا duwwan rather than mardiyyan "pleasing". This disagrees with the QCT (Q19:55). Rabin (1951, 161, §x) seems skeptical of this isogloss and calls it a "curious statement". His skepticism seems warranted, because elsewhere al-Farrā? (Lug $\bar{a} t, 92)$ is explicit in saying that it is only "some of the people of the Hijaz" that do this. Therefore, it does not appear to have been a general innovation found in all of the Hijaz.

This neutralization appears to be part of a more widespread neutralization of III- $w$ and III- $y$ in derived nominal stems. In the QCT we also see عصبيه / Iu/ișiyyu-hum/ (Q20:66, Q26:44) as the CuCūC plural of عصا 'rod'. Interestingly, the $\mathrm{CuCu} C$ verbal nouns seems to mostly keep III- $w$ and III- $y$ roots distinct. Thus, we see علوا /Yuluwwā/ (Q17:4, 43; Q27:14; Q28:83) as the verbal noun

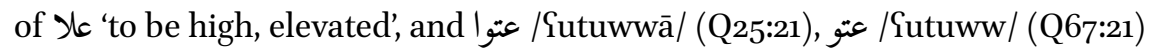
as the verbal noun of عتا 'to be insolent', whereas we find رقيك / لرقيك/li-ru/iqiyyi-ka/ (Q17:93) as the verbal noun of رقى 'to ascend' and مضيا /mu/idiyyā/ (Q36:67) as the verbal noun of مضى 'to go away'. The Quran however exploits verbal nouns that have undergone this neutralization for the purpose of rhyme in Sūrat Maryam (Q19): عتيا / ع (؟u/itiyyā/ (Q19:8, 69) as an alternative verbal noun

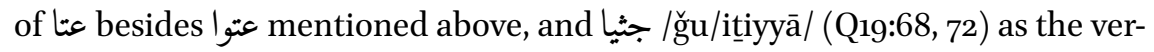
bal noun of جثt 'to kneel'.

\subsubsection{The Passive Participle of II-y Is maCìC Rather Than maCyūC}

A doubtful isogloss is the Tamīmì practice of using madyūn instead of the Hijazi madin for passive participles of II- $y$ roots (Rabin 1951, 16o, §u). As Rabin points out, it is likely that the Tamīmì form is an innovative analogical formation of the passive participle, rather than the Proto-Arabic reflex, in which case Hijazi would simply have the Proto-Arabic form. The QCT indeed has the alleged Hijazi form, but contrary to Rabin's claim, this does not occur only once in مهيلا 'poured down' (Q73:14), but also مدينون (Q37:53), مدينين (Q56:86) 'indebted; judged', مكيدون 'tricked' (Q52:42).

Sībawayh (IV, 248) does report that 'some Arabs' say mabyū $\varsigma$ 'bought' rather than $m a b i \bar{\imath}$, but he does not explicitly identify it as a non-Hijazi or Tamīmī form, nor does he identify $m a b \bar{\imath} \uparrow$ as the Hijazi form. ${ }^{16}$ The much later grammarian Ibn

16 Some of these "Tamīmi” forms have made it into the Classical Arabic language. Fischer (2002, § 247.2) mentions mabyū 'sold', which occurs besides mabī؟. Wehr (1979, s.v.) also mentions madyūn besides madīn for 'indebted'. In Classical Arabic the alleged Hijazi form is dominant. 
Ğinnī (d. 392/1002) in his Kitāb al-Muġtașab (p. 3) does identify the mabyū type as Tamīmī, but considering how late a source Ibn Ğinnī is, we should be skeptical of this attribution.

\subsubsection{Gt-stems of I-w verbs Is itazara instead of ittazara}

According to some grammarians Hijazi Arabic had itazara rather than ittazara for I-w verbs in the Gt-stem (Rabin 1951, 158f., §r). If correct, this would be an example where the QCT does not follow the Hijazi formation, cf. فاتقوا 'so fear!' (Q2:24) and السق 'to become full' (Q84:18). The identification seems doubtful however, as early sources give conflicting accounts. For example, al-Farrā? (Lug $\bar{a} t, 20$ ) explicitly attributes the form ittaqū with an initial long consonant to the people of the Hijaz, while he attributes taqu to Tamìm and Pasad. He makes no mention of a form itaqu.

\subsubsection{The Hijazi Dual Is Uninflected, Using the Nominative Form}

Rabin $(1951,156, \S \mathrm{m})$ suggests that, at least in the dialect of Mecca, the dual did not inflect for case and the nominative was used in all positions. If this is correct, then Quranic Arabic disagrees with the Meccan dialect in this regard, as the dual is fully functional. However, this dialectal explanation seems to exist exclusively as a pious explanation of the problematic reading Pinna hädāni lasāhirāni (Q20:63) (Ibn al-Ǧazarī, §359o-3591), where from a Classical Arabic grammatical perspective Pabū Yamr's hädayni would be expected. There is, of course, no a priori reason to assume that the demonstrative inflected for case in Quranic Arabic; other demonstratives do not inflect for case either. It might not be that the dual in general did not inflect in Hijazi, but that it was specifically the dual demonstratives that did not. Such an interpretation seems to be implicitly suggested (and attributed to the southern Hijazi tribe Banū alḤārit b. KaYb) by al-Farrā? (Luga ät, 94) who only mentions the non-inflecting nature of hādāni. هذن (Q20:63, Q22:19) is the only form of the masculine dual attested in the QCT, whereas the feminine is only attested as (Q28:27), there is therefore no way to confirm that the Quranic Arabic had an inflecting dual. However, the QCT also allows for a different interpretation. While the particle Pinna requires the accusative, the particle ?in with the same function requires the nominative. The QCT ان هذن لسحرن simply accommodates such a reading, and is indeed the canonical reading reported for Hafṣ fan Yāșim and Ibn Katīir.

Other case of Pin in the function of Pinna are found among several canonical readers, e.g. Q86:4 Pin kullu nafsin lamā Galayhā hăfizun "Every soul has a guardian over it" (majority reading), as opposed to Pin kullu nafsin lammā Salayha ḥăfiz "there is no soul but has a guardian over it." (Yāṣim, Ibn Yāmir, 
Ḥamzah, Pabū Ğaffar). Similar constructions with disagreement on lamā versus lammā are found in Q36:32 and Q43:35 (Ibn al-Ǧazarī, § 3312-3313).

Whatever the explanation, the use of Pin in this function, an uninflected dual deictic or even a mere mistake in the QCT - as suggested by a transmission brought by al-Farrā? (Luġāt 94f.) in which Yā?išah supposedly proclaimed this ${ }^{17}$ - this can hardly be used as evidence of an isogloss of a completely uninflecting dual in Hijazi Arabic. Note that the use of this dual is specifically used in direct speech, which Al-Jallad (2020b, 68f.) suggests may have been a context which uses explicitly colloquial features for rhetorical effect, see section $\S 4.10$ for more details.

\subsection{The Quran Is Morphologically Hijazi}

As mentioned in section $\S 4.1$ it was Rabin's claim that, while Quranic Arabic was phonologically perhaps somewhat adapted to the local Hijazi dialect, it morphologically adhered almost completely to the poetic koiné. The problem is that Rabin - nor to my knowledge any other author-ever defines what exactly the features morphological or otherwise of this poetic koiné are.

As we have elaborated upon in chapter 2 the very category of a 'poetic koiné' as opposed to 'dialects' is not a dichotomy the Arabic grammarians operated within. In fact, whenever we find Sībawayh discussing a variety of different morphological or phonological options he frequently qualifies this with a wa-kullun Sarabiyy - All is Arabic, even when these options are explicitly attributed to tribes. I think we should take these statements of the grammarians seriously. If we do not impose a dichotomy between an undefined and undescribed poetic koiné versus the dialects, and look at which dialectal features that can actually be recognized in the QCT, a rather clear picture emerges: all the morphological features attributed to the Hijaz that can be gleaned from the QCT indeed confirm that it is a Hijazi text.

It is worth appreciating just how different the view from the QCT is in comparison to what we find in the reading traditions. As I showed in chapter 3 , the reading traditions are very mixed, sound laws do not operate regularly and each reading incorporates Hijazi and non-Hijazi features in a haphazard manner and in different configurations from other readers. From the readings, no real

17 Along with two examples of seemingly mistaken case in the sound masculine plural, in both cases related to the Pin (na) and läkin(na) particles, namely lākini r-rāsixūna [...] wa-

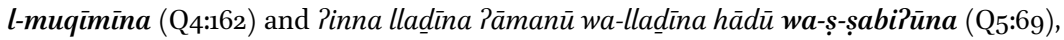
cf. the doublet of this phrase the expected case in Q22:17. 
signal from any dialect can be recovered. Therefore, it is all the more striking that the QCT gives such a regular picture. This is unlikely to be a coincidence.

Whenever we are dealing with innovative features of Hijazi Arabic, where the pre-Islamic epigraphic record can give us insight into this feature, we find that likewise the northern varieties of Safaitic and Nabataean Arabic do not appear to have undergone these innovations. This lends some credibility to the comments of the grammarians that these innovations should indeed be sought in the Hijaz. The table below summarizes the isoglosses discussed so far. Some of these cases are retentions while others are innovations, but all in all the picture is clear. Thus, let me recast Rabin's quote mentioned at the top of this section, in terms of what the linguistic evidence actually brings us: As for the Quran, in morphology we find an almost complete conformity with Hijazi Arabic has been achieved; the few Najdi forms, such as the biliteral jussive and imperative of verbs med. gem. only appear sporadically.

The table below summarizes the morphological isoglosses of Quranic Arabic that have a clear tribal attribution among the Arab grammarians. As should be clear, all of them invariably agree with Quranic Arabic being a Hijazi text. The column next to it examines the presence or absence of these isoglosses in epigraphic Old Arabic such as Nabataean Arabic, Safaitic and Hismaic. Whenever the epigraphic record allows us to discern this, we find that in these northern varieties said isoglosses are absent, which lends credence to the grammarian data that suggests these are Hijazi innovations.

\begin{tabular}{|c|c|c|}
\hline & Grammarians & Old Arabic \\
\hline ?alla-base relative pronoun & All non-Ṭayyi? tribes & North: Absent, Hijaz: Present \\
\hline Distal demonstratives with $-l(i)-$ & Hijaz & Absent \\
\hline pl.dist PulāPika (not Pulāka) & Hijaz & $?$ \\
\hline m.sg.prox $\underline{d} \bar{a}>h \bar{a}-\underline{d} \bar{a}$ & Hijaz & Absent \\
\hline f.sg.prox $(h \bar{a})-t \bar{l} / \underline{d} \bar{\imath}>h \bar{a} \underline{d} i h$ & Hijaz & Absent \\
\hline Loss of Barth-Ginsberg alternation & Hijaz & Absent \\
\hline Uninflected halumma & Hijaz & $?$ \\
\hline Uncontracted II=III imperative/apocopate & Hijaz & $?$ \\
\hline Mā Ḥiǧāziyyah & Hijaz & $?$ \\
\hline Presentative $h \bar{a} P a$ with pronominal endings & Hijaz & $?$ \\
\hline Zawğ as Wife & Hijaz & $?$ \\
\hline Lexical isoglosses of G- and C-stems & Hijaz & $?$ \\
\hline
\end{tabular}

